\title{
Analisis kandungan artemisinin pada kultur tunas Artemisia annua L. dengan lima karakter morfologi yang berbeda
}

\author{
Contents analysis of artemisinin in shoot culture of Artemisia annua L. with five \\ different morphological characteristics
}

\author{
Tri Muji Ermayanti ${ }^{1 *}$, Erwin Al Hafiizh ${ }^{1}$, Aryanti $^{2}$ dan Lenny Sutedja ${ }^{3}$ \\ ${ }^{1}$ Pusat Penelitian Bioteknologi-LIPI; ${ }^{2}$ Puslitbang Teknologi Isotop dan Radiasi-BATAN; ${ }^{3}$ Pusat Penelitian \\ Kimia-LIPI. \\ Pusat Penelitian Bioteknologi-LIPI, Jalan Raya Bogor Km 46 Cibinong 16911; Telpon 021-8754587; Fax 021- \\ 8754588; E-mail : tmermayanti@hotmail.com*Penulis untuk korespondensi
}

\begin{abstract}
Artemisia annua $\mathrm{L}$. is a medicinal plant that has an antimalarial drug againts Plasmodium falciparum strains which are resistant to traditional drugs such as quinine and chloroquine. This plant contains artemisinin as major compounds found on its leaves. Aim of the research was to analyze the artemisinin content of shoot culture of $A$. annua which has five different in leaf morphologies (Morphology type A, B, C, D and E). Previous investigation showed that shoot regenerated from callus has five different morphologies. This somaclonal variation was permanent after continuously subcultured onto MS medium with no addition of plant growth regulators. Artemisinin was detected using HPLC and it was comfirmed by LC-MS. The results showed that shoot culture type $B$ contained the highest artemisinin content $(0.171 \%)$ amongst other type of morphology. Shoot type $D$ showed the lowest level of artemisinin $(\mathbf{0 . 0 0 6} \%)$ which was not significantly different with type $\mathbf{E}$ $(0.008 \%)$. Addition of BAP at concentration of 1 and $2 \mathrm{mg} / \mathrm{l}$ increased artemisinin level of the shoot culturs.
\end{abstract}

Key words : Artemisia annua, antimalaria, shoot culture, artemisinin, leaf morphology

Diterima : 30 Agustus 2004, disetujui : 29 Oktober 2004

\section{Pendahuluan}

Artemisia annua L. (famili Compositae) merupakan salah satu tanaman obat yang sudah lama digunakan di China sebagai obat antimalaria. Tanaman ini mengandung senyawa seskuiterpen lakton yang disebut artemisinin yang merupakan bahan obat yang efektif untuk jenis-jenis malaria yang tahan terhadap klorokuin dan terhadap malaria serebral yang disebabkan oleh Plasmodium falciparum (Paniego dan Giuletti 1994). Artemisinin disintesis di akar dan diakumulasikan di daun dan bagian tanaman lainnya. Kandungan artemisinin daun merupakan $89 \%$ dari total kandungan yang terdapat pada tanaman yang sedang berbunga (van Geldre et al., 1997).

Di alam produksi artemisinin dari $A$. апnиа dipengaruhi oleh iklim, kondisi tanah, umur tanaman (Klayman, 1985) dan variasi genetik (Paniego dan Giulietti 1994). Untuk keperluan ekstraksi, 1 ton berat kering daun dapat menghasilkan 5-6 $\mathrm{kg}$ artemisinin. Keperluan ini dapat dipenuhi dengan menanam tanaman pada lahan lebih dari 40 hektar (Hien dan White 1993). Teknik kultur jaringan khususnya kultur tunas dan kultur akar merupakan salah satu metode alternatif untuk penyediaan bibit $A$. апnиa dengan kuantitas dan kualitasnya yang dapat dijaga. Metode ini juga dapat dipergunakan untuk mempelajari 
biosintesis, biotransformasi artemisinin serta untuk meningkatkan produksinya secara in vitro.

Penelitian untuk memproduksi bibit dengan kultur tunas dan kultur akar yang meliputi modifikasi medium pertumbuhan yang tepat, seleksi klon tunas dan akar rambut, konfirmasi terjadinya transformasi pada akar rambut dengan PCR dan analisis kromosom untuk mengetahui variasi dan stabilitas genetik pada kultur akar telah dilakukan (Ermayanti 2002). Penelitian ini bertujuan untuk mendeteksi kandungan artemisinin dari kultur tunas yang mempunyai lima tipe morfologi berbeda. Kultur tunas ini diperoleh dari hasil regenerasi kalus yang ditumbuhkan pada medium yang mengandung zat pengatur tumbuh sitokinin dan auksin serta air kelapa. Kadar artemisinin dari kultur tunas dengan morfologi yang berbeda juga dibandingkan dengan artemisinin dari tunas yang ditanam pada medium yang mengandung BAP.

\section{Metode Penelitian}

\section{Regenerasi tunas dari kalus}

Regenerasi tunas dari kalus dilakukan pada medium MS (Murashige and Skoog, 1962) padat yang mengandung BAP maupun NAA dengan atau tanpa penambahan air kelapa. Tunas majemuk dihitung setelah kultur berumur 10-12 minggu setelah penanaman kalus pada medium perlakuan. Struktur dan warna kalus pada masing-masing perlakuan juga diamati. Frekuensi regenerasi kalus dalam membentuk tunas diamati setelah kultur berumur tiga minggu. Untuk mempercepat pertumbuhan tunas, kalus yang mulai membentuk tunas dipindahkan pada medium MS cair yang mengandung 0,5 dan $2 \mathrm{mg} / \mathrm{l} \mathrm{BAP}$ atau $\mathrm{MS}+1 \mathrm{mg} / \mathrm{l} \mathrm{BAP}+0,1 \mathrm{mg} / \mathrm{l} \mathrm{NAA}+0,1$ $\mathrm{mg} / \mathrm{l} \mathrm{GA}{ }_{3}$ dan $\mathrm{MS}+3 \mathrm{mg} / \mathrm{l} \mathrm{BAP}+0,1 \mathrm{mg} / \mathrm{l}$ $\mathrm{NAA}+0,1 \mathrm{mg} / \mathrm{l} \mathrm{GA} 3$ (Ermayanti et al., 2002). Medium ini merupakan medium terbaik untuk pertumbuhan A.annua menurut Gulati et al., (1996). Beberapa tunas juga dipindahkan pada medium padat untuk mengetahui medium terbaik untuk perkembangan tunas. Tunas yang telah cukup besar kemudian dipindahkan pada medium MS tanpa zat pengatur tumbuh untuk perakaran.

\section{Seleksi klon tunas berdasarkan morfologi daun dan percabangan pada batang}

Seleksi klon tunas majemuk bertujuan untuk mengelompokkan klon-klon tunas yang mempunyai morfologi serupa kemudian ditumbuhkan pada medium kultur untuk selanjutnya dianalisis kandungan senyawa bioaktifnya. Kultur tunas yang dipergunakan dalam penelitian ini berasal dari tunas hasil regenerasi kalus pada medium MS yang mengandung $1 \mathrm{mg} / \mathrm{l} \mathrm{BAP}, 1 \mathrm{mg} / \mathrm{l} \mathrm{NAA}$ dan $100 \mathrm{ml} / \mathrm{l}$ air kelapa. Tunas pucuk dari tanaman stok yang tumbuh pada medium MS padat tanpa penambahan zat pengatur tumbuh diamati variasi bentuk daun yang tumbuh. Setelah dikelompokkan menurut bentuk daun dan percabangan pada batangnya yang serupa secara visual. Tunas disubkulturkan empat kali pada medium yang sama. Setelah kultur berumur 4-5 minggu sejak subkultur terakhir, 5-6 tunas yang mewakili kelompok klonnya dikeluarkan dari tabung kultur kemudian direkatkan pada kertas HVS. Kertas yang mengandung tempelan tunas dan daun kemudian dimasukkan pada 'scanner' sehingga tercetak bentuk pertunasan dan daunnya.

\section{Analisis artemisinin}

Sebelum ekstraksi artemisinin dilakukan, tunas berumur tujuh minggu dipanen dengan cara mengeluarkannya dari botol kultur. Kultur ditimbang berat basahnya, lalu dikeringkan pada suhu kamar. Setelah kering, biomassa tunas ditimbang kembali kemudian dihaluskan dan diekstraksi dengan menggunakan n-heksan selama 3 x 24 jam. Ekstrak heksan kemudian diuapkan dengan vakum hingga mendapatkan ekstrak heksan pekat. Sampel kemudian dipartisi dengan heksan : asetonitril $(1: 1)$ sehingga mendapatkan lapisan heksan dan lapisan heksan-asetonitril. Selanjutnya lapisan asetonitril-air ditambah dengan $\mathrm{NaCl}$ yang dilanjutkan dengan pengeringan dengan $\mathrm{Na}_{2} \mathrm{SO}_{4}$. Sampel diekstraksi lagi dengan 10$30 \%$ bensen dalam heksan untuk mendapatkan lapisan bensen-heksan. Lapisan asetonitril 
kemudian dievaporasi untuk mendapatkan ekstrak asetonitril yang kemudian dimasukkan dalam kolom kromatografi silika gel (200 mesh) untuk pemisahan. Sebelum pemisahan (fraksionasi), deteksi awal artemisinin dilakukan dengan metode TLC (Thin Layer Chromatography) (ElSohly et al., 1990). Fraksi-fraksi yang diperoleh dari pemisahan ini kemudian dimurnikan dengan etanol : heksan (1:4), untuk kemudian dianalisis konsentrasi artemisininnya dengan menggunakan HPLC.

Deteksi awal adanya artemisinin dengan TLC menggunakan pewarna 5\% asam fosfomolibdat yang dilarutkan dalam etanol atau dengan pereaksi serium sulfat dan vanilin sulfat. Sebagai standar dipergunakan artemisinin dari Aldrich Co, USA. Sampel yang mempunyai nilai $\mathrm{Rf}$ yang serupa dengan standar artemisinin dilanjutkan dengan fraksionasi untuk keperluan analisis kuantitatif menggunakan HPLC (van Geldre et al., 1997) menggunakan metanol sebagai eluen dengan kolom Bondapak C-18. Konfirmasi artemisinin pada sampel dilakukan dengan penambahan standar artemisinin ke dalam sampel kemudian dilakukan analisis HPLC untuk kedua kalinya sehingga dapat dipastikan bahwa sampel tersebut mengandung artemisinin. Setelah itu hasil analisis dihitung secara kuantitatif dengan cara membandingkan area sampel dan area standar artemisinin dari puncak yang mempunyai nilai Rt (waktu retensi) yang sama. Konversi hasil perhitungan terhadap berat ekstrak sampel menghasilkan prosentase artemisinin yang terdapat pada setiap sampelnya. Analisis artemisinin dengan HPLC merupakan rata-rata dari tiga kali ulangan.

Konfirmasi artemisinin pada beberapa sampel dianalisis dengan menggunakan LCMS (Mariner Mass Spectra) (HP-11003 Mariner Biospectrometry) menggunakan kolom RP 18 dengan ukuran panjang kolom $250 \mathrm{~mm}$, diameter 4,6 $\mathrm{mm}$ dengan eluen metanol : air $=9: 1$, detektor UV-Vis yang dibaca pada panjang gelombang $\mathrm{UV}=254 \mathrm{~nm}$. Flow rate sampel adalah $0,5 \mathrm{~mm} / \mathrm{menit}$.

\section{Hasil dan Pembahasan}

\section{Regenerasi tunas dari kalus}

Setelah berumur tiga minggu pada medium perlakuan, kalus membentuk tunas dengan frekuensi regenerasi $100 \%$, namun dalam perkembangannya, tunas tumbuh dengan lambat dan jumlah tunas majemuk yang terbentuk bervariasi tergantung pada zat pengatur tumbuh yang ditambahkan pada medium. Struktur kalus dan jumlah tunas majemuk yang dihasilkan bervariasi tergantung pada medium tumbuhnya (Tabel 1).

Tabel 1. Struktur dan warna kalus, dan jumlah tunas majemuk yang dihasilkan pada medium MS yang mengandung berbagai zat pengatur tumbuh

\begin{tabular}{llc}
\hline \hline \multicolumn{1}{c}{ Zat pengatur tumbuh } & Struktur dan warna kalus & Jumlah tunas per kalus \\
\hline \hline Tanpa & Kompak, hijau & 0 \\
BAP $(1 \mathrm{mg} / \mathrm{l})$ & Friabel, putih kekuningan & $1-3$ \\
BAP $(3 \mathrm{mg} / \mathrm{l})$ & Kompak, kecoklatan & $1-3$ \\
BAP $(0,5 \mathrm{mg} / \mathrm{l})+\mathrm{AK}(100 \mathrm{ml} / \mathrm{l})$ & Friabel, hijau kelam & $4-6$ \\
$\mathrm{BAP}(1 \mathrm{mg} / \mathrm{AK}(100 \mathrm{ml} / \mathrm{l})$ & Friabel, putih & $2-6$ \\
$\mathrm{BAP}(2 \mathrm{mg} / \mathrm{l})+\mathrm{AK}(100 \mathrm{ml} / \mathrm{l})$ & Friable, putih kehijauan & $4-8$ \\
$\mathrm{NAA}(0,5 \mathrm{mg} / \mathrm{l})+\mathrm{AK}(100 \mathrm{ml} / \mathrm{l})$ & Friabel, hijau & $3-7$ \\
$\mathrm{NAA}(1 \mathrm{mg} / \mathrm{l})+\mathrm{AK}(100 \mathrm{ml} / \mathrm{l})$ & Friabel, hijau & $4-8$ \\
$\mathrm{NAA}(2 \mathrm{mg} / \mathrm{l})+\mathrm{AK}(100 \mathrm{ml} / \mathrm{l})$ & Friabel, hijau & $1-6$ \\
BAP $(1 \mathrm{mg} / \mathrm{l})+\mathrm{NAA}(1 \mathrm{mg} / \mathrm{l})+\mathrm{AK}(100 \mathrm{ml} / \mathrm{l})$ & Friabel, putih kehijauan & $3-8$ \\
\hline \hline
\end{tabular}

Keterangan : $\mathrm{AK}=$ air kelapa

Untuk meningkatkan pertumbuhannya, tunas dikulturkan pada medium cair. Tunas yang dikulturkan pada medium cair dengan jembatan kertas saring tumbuh lebih cepat dibandingkan dengan tunas yang dikulturkan pada medium padat, namun daun-daunnya cepat menguning. Oleh sebab itu setelah tunas berukuran lebih dari $1 \mathrm{~cm}$, pucuk tunas 
dipotong kemudian dipindahkan pada medium padat. Dengan cara ini pertumbuhan daun tetap hijau. Penambahan NAA maupun $\mathrm{GA}_{3}$ pada medium yang mengandung BAP tidak memberikan pengaruh terhadap perkembangan tunas. Pada medium MS padat tanpa penambahan zat pengatur tumbuh tunas mempunyai penampakan yang tegar dengan batang yang lebih besar dan daun berwarna hijau gelap serta membentuk akar dengan baik. Selanjutnya tunas diperbanyak pada medium ini dan disubkultur secara rutin untuk mengamatan variasi morfologi.
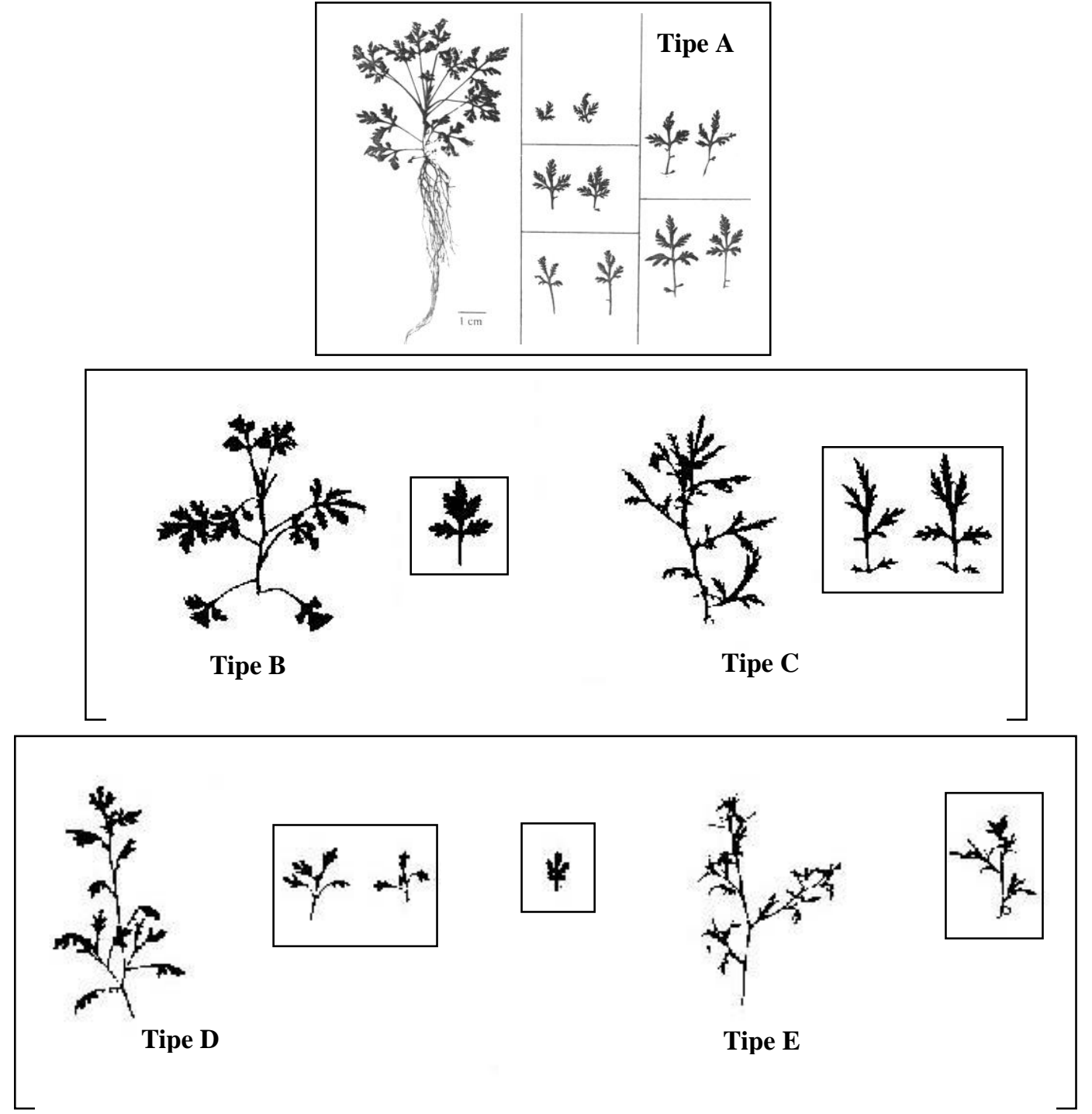

Gambar 1. Lima klon tunas Artemisia апnиa dengan variasi morfologi dan tata letak daun dan contoh gambar helai daunnya

Pada kisaran konsentrasi tertentu, kombinasi BAP dan NAA menghasilkan frekuensi regenerasi tunas dari kalus A. аппиа yang cukup tinggi (Jha et al., 1988; Paniego and Giulietti, 1994), namun kombinasi konsentrasi kedua hormon tersebut berpengaruh tergantung dari jenis dan umur eksplan yang dipergunakan. Multiplikasi tunas A. апnиa terbaik diperoleh pada medium MS yang mengandung $2 \mathrm{mg} / \mathrm{l}$ BAP (Jha et al., 1988). Penambahan zat pengatur tumbuh yang kompleks seperti kombinasi antara BAP, NAA dan $\mathrm{GA}_{3}$ dapat menyebabkan tanaman mengalami pembungaan secara in vitro (Gulati 
et al., 1996). Walaupun keberhasilan mikropropagasi tergantung dari banyak faktor, modifikasi beberapa kombinasi zat pengatur tumbuh baik jenis dan konsentrasinya perlu dicobakan untuk mendapatkan pertumbuhan pada setiap tahapan mikropropagasi $A$ аппиа yang optimum, dengan demikian dapat diperoleh protokol mikropropagasi yang standar.

\section{Seleksi klon tunas berdasarkan morfologi daun dan percabangan pada batang}

Penggolongan morfologi kultur tunas menghasilkan lima klon tunas (tipe A, B, C, D dan E) yang berbeda berdasarkan morfologi daun dan tata letak daun pada batang (Gambar 1). Karakteristik masing-masing tipe disajikan pada Tabel 2.

Di alam tanaman $A$. annua mempunyai daun tunggal yang berbentuk menyirip (pinnatipartitus) berbagi tiga atau lima dengan masing-masing bagian daun berujung meruncing. Duduk daunnya berseling membentuk roset pada batangnya. Batangnya merupakan batang tunggal yang tidak mempunyai percabangan. Adanya variasi morfologi tunas hasil kultur jaringan baik yang bersifat permanen maupun sementara belum pernah dilaporkan pada penelitian-penelitian sebelumnya.

Tabel 2. Karakter morfologi daun lima tipe klon tunas

\begin{tabular}{|c|c|}
\hline Klon tunas & Karakter \\
\hline Tipe A & $\begin{array}{l}\text { Morfologi daun seperti tanaman normal dengan ukuran daun lebih kecil, tidak membentuk } \\
\text { cabang pada batangnya. }\end{array}$ \\
\hline Tipe B & $\begin{array}{l}\text { Morfologi daun menyerupai tipe A, tetapi berukuran lebih kecil. Susunan daun tidak } \\
\text { berbentuk roset, mempunyai ruas yang lebih panjang, ukuran batang lebih kecil dari tipe A, } \\
\text { tidak membentuk tunas lateral. }\end{array}$ \\
\hline Tipe C & $\begin{array}{l}\text { Daun menyirip berbagi sangat dalam sehingga mempunyai lekuk-lekuk daun runcing yang } \\
\text { sangat kecil. Pada buku-buku batangnya tumbuh beberapa daun yang sangat kecil dan } \\
\text { membentuk tunas lateral pada bukunya. }\end{array}$ \\
\hline Tipe D & $\begin{array}{l}\text { Daun memiliki sifat antara tipe B dan C. mempunyai batang yang halus seperti tipe B tetapi } \\
\text { dengan pola percabangan dan letak daun pada batangnya seperti tipe C. Ukuran batang dan } \\
\text { daun lebih kecil dari tipe A maupun B. Batang mempunyai percabangan yang jelas. }\end{array}$ \\
\hline Tipe E & $\begin{array}{l}\text { Ukuran batang dan daun paling kecil diantara keempat tipe lainnya. Permukaan batangnya } \\
\text { halus dan mempunyaipercabangan yang jelas seperti tipe D. }\end{array}$ \\
\hline
\end{tabular}

\section{Analisis artemisinin}

Hasil analisis HPLC menunjukkan bahwa sampel mempunyai puncak dengan nilai Rt (waktu retensi) yang serupa dengan standar artemisinin (Aldrich Co. USA). Penghitungan kadar artemisinin pada kultur tunas yang ditanam pada berbagai medium tertera pada Tabel 3. Hasil penelitian menunjukkan bahwa tunas dengan tipe morfologi yang berbeda mempunyai kadar artemisinin yang bervariasi. Tunas dengan morfologi tipe $\mathrm{B}$ mempunyai kandungan artemisinin tertinggi sangat berbeda nyata dari semua tunas tipe lain maupun kultur yang ditanam pada medium yang mengandung BAP dan tunas hasil regenerasi dari kalus setelah dua kali subkultur, sedangkan tunas dengan morfologi tipe $\mathrm{D}$ mempunyai kandungan artemisinin terendah diantara keempat tipe morfologi lainnya, yang secara statistik tidak berbeda nyata dengan artemisinin dari kultur tunas tipe E (Tabel 3). Kelima tipe morfologi ini mempunyai kandungan artemisinin yang lebih tinggi dibandingkan dengan tunas yang ditanam pada medium MS padat tanpa penambahan zat pengatur tumbuh yang berasal dari kultur tunas pucuk, bukan hasil regenerasi dari kalus (Tabel 3). Analisis artemisinin pada tunas hasil regenerasi kalus hasil subkultur kedua mempunyai kandungan artemisinin yang cukup rendah tidak berbeda nyata dengan kultur tunas tipe $\mathrm{D}$ dan $\mathrm{E}$. Analisis artemisinin dari sampel ini merupakan campuran kultur tunas, tanpa memisahkan tipe morfologi yang berbeda. Penambahan BAP ke dalam medium terutama dengan konsentrasi 1 
dan $2 \mathrm{mg} / \mathrm{l}$ meningkatkan kadar artemisinin, sedangkan penambahan BAP pada konsentrasi $0,5 \mathrm{mg} / \mathrm{l}$ tidak memberikan pengaruh terhadap kadar artemisinin seperti pada tunas yang ditumbuhkan pada medium tanpa penambahan BAP.

Tabel 3. Kandungan artemisinin pada kultur tunas A. аппиа

\begin{tabular}{lc}
\hline \hline Sampel & \% artemisinin dari berat kering \\
\hline \hline Tunas dari tipe A & $0,069 \pm 0,0025^{\mathrm{f}}$ \\
Tunas dari tipe B & $0,171 \pm 0,0009^{\mathrm{g}}$ \\
Tunas dari tipe C & $0,028 \pm 0,0010^{\mathrm{d}}$ \\
Tunas dari tipe D & $0,006 \pm 0,0008^{\mathrm{b}}$ \\
Tunas dari tipe E & $0,008 \pm 0,0020^{\mathrm{b}}$ \\
Tunas dari medium MS tanpa BAP & $0,002 \pm 0,0007^{\mathrm{a}}$ \\
Tunas dari medium MS + 0,5 mg/l BAP & $0,002 \pm 0,0011^{\mathrm{a}}$ \\
Tunas dari medium MS + 1 mg/l BAP & $0,025 \pm 0,0014^{\mathrm{c}}$ \\
Tunas dari medium MS + 2 mg/l BAP & $0,038 \pm 0,0008^{\mathrm{e}}$ \\
Tunas dari regenerasi kalus* & $0,005 \pm 0,0011^{\mathrm{b}}$ \\
\hline \hline
\end{tabular}

Keterangan : *hasil subkultur ke-2; Angka yang diikuti huruf yang sama tidak berbeda nyata pada uji DMRT 1\%

Hasil penelitian ini mendukung hasil penelitian sebelumnya yang juga pada percobaan dengan A. апnиa (Ferreira et al., 1995) yang melaporkan bahwa kandungan artemisinin baik dari tanaman yang tumbuh di rumah kaca, di lapangan dan kultur jaringan mempunyai variasi yang nyata. Kadar artemisinin tanaman di rumah kaca juga tergantung dari musim dan lamamya hari disepanjang tahunnya. Kadar artemisinin tertinggi diperoleh pada saat tanaman telah berbunga. Tanaman hasil aklimatisasi planlet mempunyai kandungan artemisinin yang lebih tinggi dibandingkan dengan artemisinin yang langsung diekstrak dari kultur tunas. Dari hasil penelitian ini disimpulkan bahwa kandungan artemisinin sangat tergantung pada genotip, faktor lingkungan, umur tanaman dan metode kultivasi (Ferreira et al., 1995). Tunas yang mempunyai morfologi yang bervariasi pada penelitian ini kemungkinan juga mempunyai ukuran, bentuk atau jumlah trikoma yang berbeda sehingga mempunyai kadar artemisinin yang berbeda. Trikoma daun $A$. аппиа kemungkinan sangat berhubungan dengan kadar artemisinin karena artemisinin diakumulasikan pada sel-sel di bawah kelenjar trikoma (Duke et al., 1994).

Untuk meningkatkan produksi artemisinin pada kultur tunas A. аппиа perlu dilakukan pengakaran tunas yang telah terbentuk, karena tunas yang telah mempunyai akar (planlet) mempunyai kandungan

Biota Vol. X (3), Oktober 2005 artemisinin yang lebih tinggi dibandingkan dengan tunas yang belum berakar (Ferreira and Janick, 1996). Untuk mempelajari produksi artemisinin pada skala yang lebih besar, tunas dapat ditumbuhkan pada bioreaktor. Dengan menggunakan 'inner-loop mist bioreactor' dapat diketahui kinetika pertumbuhan kultur tunas dan produksi optimum artemisinin pada kultur (Liu et al., 1998).

\section{Kesimpulan}

Regenerasi tunas dari kalus $A$ annua pada medium MS tanpa zat pengatur tumbuh menghasilkan lima morfologi yang berbeda. Analisis artemisinin dengan menggunakan HPLC menunjukkan bahwa morfologi tunas yang berbeda menghasilkan kadar artemisinin yang bervariasi. Tunas dengan morfologi tipe B mempunyai kandungan artemisinin tertinggi dibandingkan dengan tipe morfologi lainnya. Kandungan artemisinin ini lebih tinggi dibandingkan dengan tunas dari kultur ujung tunas maupun dari tunas hasil regenerasi kalus setelah mengalami dua kali subkultur. Penambahan 1-2 $\mathrm{mg} / \mathrm{l} \quad$ BAP dapat meningkatkan kandungan artemisinin pada tunas. 


\section{Ucapan Terima Kasih}

\author{
Penulis mengucapkan terima kasih \\ kepada Balai Penelitian Tanaman Obat, \\ Cimanggu-Bogor yang telah membantu analisis \\ artemisinin dengan HPLC. Penelitian ini \\ merupakan bagian penelitian RUT VIII dengan \\ judul 'Pengembangan kultur tunas dan kultur \\ akar Artemisia annua L. penghasil obat \\ antimalaria artemisinin.
}

\section{Daftar Pustaka}

Duke, M.V., Paul, R.N., Elsohly, H.N., Sturtz, G. and Duke, S.O. 1994. Localization of artemisinin and artemisitene in foliar tissues of glanded and glandless biotypes of Artemisia annua L. International Journal of Plant Sciences 55 : 365-372.

ElSohly, H.N., Croom, Jr. E.M., El-Feraly, F.S. and ElSherei, M.M. 1990. A large-scale extraction technique of artemisinin from Artemisia annua. Journal of Natural Product 53 (6) : 1560-1564.

Ermayanti, T.M. 2002. Pengembangan kultur tunas dan kultur akar Artemisia annua $\mathrm{L}$ penghasil obat antimalaria artemisinin. Laporan Riset Unggulan Terpadu (RUT) VIII Tahap II. Pusat Penelitian Bioteknologi LIPI.

Ermayanti, T.M., Andry, Y., Wulandari, D.R. and Al Hafiizh, E. 2002. Mikropropagasi Artemisia cina dan A. annua L. Makalah Seminar Nasional Pemanfaatan dan Pelestarian Plasma Nutfah. IPB, 3-4 September 2002. Bogor.

Ferreira, J.F.S. and Janick, J. 1996. Roots as enhancing factor for the production of artemisinin in shoot cultures of Artemisia annua. Plant Cell Tissue and Organ Culture 44 : 211-217.
Ferreira, J.F.S., Simon, J.E. and Janick, J. 1995. Relationship of artemisinin content of tissuecultured, greenhouse-grown, and field-grown plants of Artemisia annua. Planta Medica. 61 : 351-355.

Gulati, A., Bharel, S., Jain, S.K., Abdin, M.Z. and Srivastava, P.S. 1996. In vitro micropropagation and flowering in Artemisia annua. Journal of Plant Biochemistry and Biotechnology 5 : 31-35.

Hien, T.T. and White, N.J. 1993. Tissue culture of Artemisia annua L-a potential source of an antimalarial drug. Qinghaosu. Lanset 341 : 603-608.

Jha, S., Jha, T.B. and Mahato, S.B. 1988. Tissue culture of Artemisia annua L.-A potential source of an antimalarial drug. Current Science. 57 (6) : 344-346.

Klayman, D.L. 1985. Qinghaosu (artemisinin) : An antimalarial drug fron China. Science 228 : 1049-1055.

Liu, C-Z., Wang, Y-C., Guo, C., Ouyang, F., Ye, H-C. and Li, G-F. 1998. Production of artemisinin by shoot cultures of Artemisia annua L. in a modified inner-loop mist bioreactor. Plant Science. 135 : 211-217.

Murashige, T. and Skoog, F. 1962. A Revised Medium for Rapid Growth and Bioassays with Tobacco Tissue Cultures. Physiologia Plantarum 15 : 473-497.

Paniego, N.B. and Giuletti, A.M. 1994. Artemisia annua L. : dedifferentiated and differentiated cultures. Plant Cell, Tissue and Organ Culture 36 : 163-168.

Van Geldre, E., Vergauwe, A. and van den Eeckhout, E. 1997. State of the art of the production of the antimalarial compound artemisinin in plants. Plants Molecular Biology 33 : 199-209. 